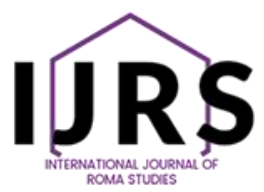

Hipatia Press

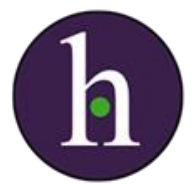

Instructions for authors, subscriptions and further details:

http://ijrs.hipatiapress.com

\title{
COVID-19 Crisis: Impact on households of the Roma community
}

Javier Arza Porras ${ }^{1}$, Diana Gil-González ${ }^{2}$, Lluís Català-Oltra Francisco Francés García ${ }^{3}$, María Eugenia González Angulo ${ }^{4}$, Maria Félix Rodríguez Camacho ${ }^{4}$, María José Sanchís Ramón ${ }^{3}$, Belén Sanz-Barbero ${ }^{5}$, Carmen Vives-Cases ${ }^{2}$, Daniel La Parra Casado ${ }^{3}$

1) Public University of Navarre, Spain

2) University of Alicante. CIBER of Epidemiology and Public Health, Spain

3) University of Alicante, Spain

4) FAGA. Equi-Sastipen-Rroma Network, Spain

5) Instituto de Salud Carlos III. CIBER of Epidemiology and Public Health, Spain

Date of publication: September $15^{\text {th }}, 2020$

Edition period: March 2020 - September 2020

To cite this article: Arza Porras, J., Gil-González, D., Català-Oltra, L. et al. (2020). COVID-19 Crisis: Impact on households of the Roma community. International Journal of Roma Studies, 2(2), 28-51. doi:

10.17583/ijrs.2020.6242

To link this article: http://dx.doi.org/10.17583/ijrs.2020.6242

\section{PLEASE SCROLL DOWN FOR ARTICLE}

The terms and conditions of use are related to the Open Journal System and to Creative Commons Attribution License (CCAL). 


\section{COVID-19 Crisis: impact on households of the Roma community}

Javier Arza Porras

Public University of Navarre

Diana Gil-González

University of Alicante

CIBER of Epidemiology and Public

Health, Spain

Lluís Català-Oltra

University of Alicante

Francisco Francés García

University of Alicante

María Eugenia González Angulo

FAGA

Equi-Sastipen-Rroma Network
María Félix Rodríguez Camacho

FAGA

Equi-Sastipen-Rroma Network

María José Sanchís Ramón

University of Alicante

Belén Sanz-Barbero

Instituto de Salud Carlos III

CIBER of Epidemiology and Public

Health, Spain

Carmen Vives-Cases

University of Alicante

CIBER of Epidemiology and Public

Health, Spain

Daniel La Parra Casado

University of Alicante

\section{Abstract}

The aim of this study is to analyse the impact that COVID-19 has had on the Roma population in Spain, showing results of a telephone interview on a sample of 592 Roma households in the more restrictive phase of lockdown (phase 0 of the de-escalation period to gradually lift confinement). This study has been developed by means of an alliance in which researchers from the public universities of Alicante and Navarre and the Health Institute Carlos III have participated, as well as several Roma associations. The results reflect the significant impact that the pandemic has caused in households that were already affected by social exclusion and inequality. Thus, a worsening of self-perception of health and a high rate of anxiety or depression problems were detected, the impact of which goes beyond health and affects all dimensions of social inclusion. In education, half of the households refer to minors having difficulties continuing their studies from home. A similar percentage have had their jobs affected and have seen a significant reduction in income. In addition to the aforementioned problems, perceived discrimination is also added.

Keywords: COVID-19, inequalities, health, social exclusion, Roma.

2020 Hipatia Press

ISSN: 2462-425X

DOI: $10.17583 /$ ijrs.2020.6242 


\section{La crisis de la COVID-19: impacto en los hogares de familias gitanas}

Javier Arza Porras

Universidad Pública de Navarra

Diana Gil-González

Universidad de Alicante

CIBER de Epidemiología y Salud

Pública, España

Lluís Català-Oltra

Universidad de Alicante

Francisco Francés García

Universidad de Alicante

María Eugenia González Angulo

FAGA

Red Equi-Sastipen-Rroma

\author{
María Félix Rodríguez Camacho \\ FAGA \\ Red Equi-Sastipen-Rroma \\ María José Sanchís Ramón \\ Universidad de Alicante \\ Belén Sanz-Barbero \\ Instituto de Salud Carlos III \\ CIBER de Epidemiología y Salud \\ Pública, España \\ Carmen Vives-Cases \\ Universidad de Alicante \\ CIBER de Epidemiología y Salud \\ Pública, España
}

Daniel La Parra Casado

Universidad de Alicante

\section{Resumen}

El objetivo de este estudio es analizar el impacto que ha tenido el COVID-19 en la población gitana en España, mostrando los resultados de una entrevista telefónica a una muestra de 592 hogares gitanos en la fase más restrictiva del confinamiento (fase 0 del período de desescalada para levantar gradualmente el confinamiento). Este estudio se ha desarrollado mediante una colaboración en la que han participado investigadores de las universidades públicas de Alicante y Navarra y del Instituto de Salud Carlos III, así como varias asociaciones gitanas. Los resultados reflejan el impacto significativo que la pandemia ha causado en hogares que ya estaban afectados por la exclusión social y la desigualdad. Así, se detectó un empeoramiento de la autopercepción de la salud y una alta tasa de problemas de ansiedad o depresión, cuyo impacto va más allá de la salud y afecta a todas las dimensiones de la inclusión social. En educación, la mitad de los hogares se refieren a menores con dificultades para continuar sus estudios desde casa. Un porcentaje similar ha visto afectados sus trabajos y ha visto una reducción significativa en los ingresos. Además de los problemas antes mencionados, también se suma la discriminación percibida.

Palabras clave: COVID-19, desigualdades, salud, exclusión social, gitanos.

2020 Hipatia Press

ISSN: $2462-425 \mathrm{X}$

DOI: $10.17583 / \mathrm{ijrs} .2020 .6242$ 


\section{Arza Porras, et al. - COVID-19 crisis in the Roma community}

O n 14th March, the state of alarm was declared in Spain due to the health crisis caused by COVID-19. Since the very start of the pandemic, Roma associations began to worry about the impact that it could have on Roma families with whom they worked. Therefore, the Federación FAGA Alicante contacted the professors at the University of Alicante and the Public University of Navarre to consider the possibility of collecting information via telephone on the impact that COVID-19 was having on Roma families who use their services. After designing the initial questionnaire, and with the collaboration of FAGA of Alicante and the State network Equi-Sastipen-Rroma of Roma associations, Roma entities from other territories were included in the project, which allowed us to reach different social, economic and political contexts. Finally, the telephone interview was initiated with Roma families who used FAGA (Alicante, Valencia, Castellón and Murcia), UNGA (Asturias), Federación Gaz Kalo (Navarre), Red Artemisa (Madrid) and Nevipen (Vizcaya), with the aim of learning about the effects the pandemic could have in terms of their health, work and economic situation, as well as experiences of discrimination and school careers of Roma students.

This study was part of a broader scientific interest; therefore institutions and research teams are trying to urgently respond to the challenge of analysing the differential impact of COVID-19 on parts of society previously affected by exclusion and social inequality. Some of these studies have focused on analysing the impact of the pandemic on the population that is socially excluded (Cáritas, 2020), others on ethnic groups (Platt and Warwick, 2020), and even others have expressly referred to the Roma population (FSG, 2020; Central Council of German Sinti and Roma, 2020).

In addition, the study is associated with lines of research that analyse the health situation of the Roma population from a social determinants of health approach (La Parra, Arza y Estévez, 2020; La Parra, Gil and de la Torre, 2016; Cook, Wayne, Valentine, Lessios and Yeh, 2013; Janevic, Jankovic and Bradley, 2012; Vokó, Németh, Kósa, Kósa, Széles and Ádány, 2009). Therefore, the intention is to observe the interaction between health and the level of education, income, social and institutional discrimination, employment, housing and other social factors that have an influence on health. 
In Spain, there is an added difficulty to this kind of study consisting of the fact that there is no systematised institutional system to collect information that would allow us to delve into the specific health conditions that the Roma population face. In order to compensate this flaw, the Spanish Ministry of Health initiated research in 2006 to compare the results of a national survey on health in terms of the results obtained in a survey specifically applied to the Roma population (MSPS/FSG, 2009; MSSSI, 2016). Up to now, one was carried out in 2006 and another in 2014. Some of the authors who sign this article have taken part in developing a second survey which also included collaboration with Roma associations.

Based on this, and characterised by the difficulty in accessing information, this article intends to establish the multidimensional impacts that the pandemic has caused in Roma families who use the services of different Roma entities within in Spain. The information collected included employment, social-health and educational needs.

\section{Methods}

\section{Study Design}

Exploratory research carried out via computer-assisted telephone interviewing (CATI) to households part of the network of five Roma associations in the social scope, designed to be applied at the beginning of the state of alarm and before the end of phase 0 of the de-escalation period to gradually lift lockdown (lockdown in Spain was lifted gradually through de-escalation measures, which were divided into phase 0, 1, 2 and 3. Each phase had a series of restrictions allowing society to enter the new normality). Fieldwork began on 12th April and ended on 10th May 2020.

This is an urgent research (inspired by the methodological currents encompassed under the title of "Participatory Rapid Appraisal"). In this sense, the topic of this research was proposed by the community entities (FAGA), which was established in the initial design of the draft questionnaire that defined the subject matters and main issues to be approached. The questionnaire was adapted by the research team to the required format for a CATI questionnaire. In order to carry out the field work, the participating entities used their own resources, especially to 


\section{Arza Porras, et al. - COVID-19 crisis in the Roma community}

access their user population in order to establish the sample, and personnel to conduct the interviews, for which the research team organised specific training sessions. In addition, the personnel of the entities took part in the interpretation of the results and triangulation with their knowledge based on their experience, introducing qualitative comments from the team of interviewers when carrying out the analysis. A virtual forum was organised for this purpose through Google Groups. This allowed us to proceed by guaranteeing compliance with the ethical principles of inclusive research in order to minimise the risk of creating stereotyped and prejudiced knowledge towards the Roma population, and due to the fact that this research intends to respond to the needs raised by the community itself (European Commission, 2015). Nonetheless, the research complies with the main deontological principles of information, protection of anonymity, confidentiality and wilfulness, as well as complying with the Spanish legislation on personal data protection.

\section{Territorial scope}

Questionnaire aimed at households served by five Roma entities, whose work was territorially limited (FAGA in the Region of Valencia and Murcia, UNGA in Asturias, Gaz Kalo in Navarre, Red Artemisa in Madrid and Nevipen in Bizkaia).

\section{Sampling}

Non-probability sampling based on a selection of households from among those served by the entities participating in the study. It was also based on criteria to maximise the diversity of the sample according to characteristics such as territorial dispersion (municipalities and neighbourhoods) and programme diversity (education, employment, health, legal advice, etc.).

As already indicated, this is a non-probability sampling that, as a result, does not allow the margin of error and confidence level to be calculated, nor does it allow statistical inference on a population scale or extrapolation of results to a theoretical population context. The selected households meet the profile of being households of Roma families that take part in the different intervention programmes of Roma entities. In order to demonstrate 
the global data in the study, we have chosen to apply a weighting via a simple allocation that balances the weight of each entity/territory in the overall result (see Table 1). However, as the sample population of the five territories is not specifically known, both absolute and relative figures must be understood as an approximation.

Table 1

Weighting coefficient for entities

\begin{tabular}{rcccccc} 
& & $\begin{array}{c}\text { Theoretical } \\
\text { distribution } \\
\text { (simple } \\
\text { affixation per } \\
\text { entity) (abs.) }\end{array}$ & $\begin{array}{c}\text { Theoretical } \\
\text { distribution } \\
(\%)\end{array}$ & $\begin{array}{c}\text { Real } \\
\text { distribution } \\
\text { of sample } \\
\text { (abs.) }\end{array}$ & $\begin{array}{c}\text { Real } \\
\text { distribution } \\
\text { of sample } \\
(\mathbf{\%})\end{array}$ & $\begin{array}{c}\text { Weighting } \\
\text { coefficient }\end{array}$ \\
\hline FAGA & Alicante & 33 & 6.7 & 141 & 23.8 & .24 \\
FAGA & Valencia & 33 & 6.7 & 63 & 10.6 & .53 \\
FAGA & Murcia & 33 & 6.7 & 33 & 5.6 & 1.01 \\
Gaz Kaló & Bizkaia & 100 & 20.0 & 96 & 16.2 & 1.04 \\
$\begin{array}{r}\text { Red } \\
\text { Artemisa }\end{array}$ & Navarre & 100 & 20.0 & 93 & 15.7 & 1.08 \\
Nevipen & Asturias & 100 & 20.0 & 91 & 15.4 & 1.10 \\
Unga & Madrid & 100 & 20.0 & 75 & 12.7 & 1.33 \\
\hline & & $\mathbf{5 0 0}$ & $\mathbf{1 0 0 . 0}$ & $\mathbf{5 9 2}$ & $\mathbf{1 0 0 . 0}$ & \\
\hline
\end{tabular}

\section{Characteristics of the participating households}

The sample includes a total of 592 households, distributed into five participating entities. $96.5 \%$ of the total contacted households answered the questionnaire. There is a high response rate that is explained by previous contact between Roma entities and the selected households. Those who refused to participate explain that their reasons are based on clashing with other tasks, connection problems, and refusal to discuss COVID-19. 
32 Arza Porras, et al. - COVID-19 crisis in the Roma community

Table 2 shows the main descriptive data of the participating households in the study:

Table 2

Characteristics of interviewed population in terms of entity

\begin{tabular}{|c|c|c|c|c|c|c|c|}
\hline & & $\begin{array}{c}\text { No. } \\
\text { interview } \\
\quad \mathrm{s}\end{array}$ & $\begin{array}{c}\% \\
\text { women } \\
\text { informers }\end{array}$ & $\begin{array}{l}\text { Average } \\
\text { age of } \\
\text { informer }\end{array}$ & $\begin{array}{l}\text { Averag } \\
\text { e No. } \\
\text { membe } \\
\text { rs in } \\
\text { househ } \\
\text { old }\end{array}$ & $\begin{array}{l}\text { Average } \\
\text { No. } \\
\text { minors in } \\
\text { househol } \\
\quad \text { d }\end{array}$ & $\begin{array}{c}\text { Average \% } \\
\text { minors in } \\
\text { household }\end{array}$ \\
\hline \multirow{6}{*}{ 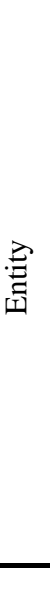 } & $\begin{array}{r}\text { FAGA } \\
\text { (Region of } \\
\text { Valencia- } \\
\text { Murcia) }\end{array}$ & 237 & 66.5 & 39.23 & 4.12 & 1.48 & 35.9 \\
\hline & $\begin{array}{r}\text { Gaz Kalo } \\
\text { (Navarre) }\end{array}$ & 93 & 79.1 & 38.50 & 4.32 & 1.67 & 38.7 \\
\hline & $\begin{array}{r}\text { Red } \\
\text { Artemisa } \\
\text { (Madrid) }\end{array}$ & 75 & 85.3 & 37.37 & 4.45 & 1.68 & 37.8 \\
\hline & $\begin{array}{r}\text { Nevipen } \\
\text { (Bizkaia) }\end{array}$ & 96 & 83.7 & 39.12 & 5.09 & 2.37 & 46.6 \\
\hline & $\begin{array}{r}\text { UNGA } \\
\text { (Asturias) }\end{array}$ & 91 & 54.0 & 39.72 & 3.54 & 1.01 & 28.5 \\
\hline & Total & 592 & 71.8 & 38.94 & 4.26 & 1.61 & 37.8 \\
\hline
\end{tabular}

\section{Characteristics of the survey}

The study's unit of analysis has been the household. The information collected in each questionnaire has mainly referred to characteristics shared by the household as a whole, although some indicators collect information and opinions referring to the interviewed person. The size of the sample and the dynamics of the telephone interview situation make it necessary to collect the information through direct questions, with few filters, and with a simple structure. This is a cross-sectional survey that includes questions with different time frames of reference, distinguishing between the situation 
prior to confinement and when the interview was conducted (during the strictest phase of the de-escalation period) for several questions. The questions are inspired by those used in official studies, such as the National Health Survey by the Spanish Statistics Institute and the European UnionSILC (Statistics of Income and Living Conditions survey, by Eurostat).

Table 3 shows the descriptions of the variables considered in the questionnaire.

Table 3

Variables of survey

Variables

Description

\begin{tabular}{l|l}
\hline Health & $\begin{array}{l}\text { Evolution of self-perceived health (before-during } \\
\text { confinement); COVID-19 cases in the home; symptoms; } \\
\text { other health problems; type of treatment/care received. }\end{array}$ \\
\hline Discrimination & $\begin{array}{l}\text { Evolution of the perception of discrimination (before- } \\
\text { during confinement); experienced discrimination; } \\
\text { degree of concern about discrimination. }\end{array}$ \\
\hline Family life & $\begin{array}{l}\text { Evolution of the relationship with household members } \\
\text { (before-during confinement). }\end{array}$ \\
\hline Studies & $\begin{array}{l}\text { Evolution in meeting household needs (before-during } \\
\text { confinement); spaces and services that the house has. }\end{array}$ \\
\hline Employment & $\begin{array}{l}\text { Children schooled at home and type of studies; possible } \\
\text { factors that make it difficult to follow the studies from } \\
\text { home. }\end{array}$ \\
\hline Income & $\begin{array}{l}\text { People who have had to leave the home for work } \\
\text { reasons and the protective measures they have had; } \\
\text { people who have been able to work from home; people } \\
\text { whose employment has been affected during } \\
\text { confinement. }\end{array}$ \\
\hline $\begin{array}{l}\text { Evolution in the number of people who contribute } \\
\text { income to the household (before-during confinement); } \\
\text { income threshold of the household; evolution in } \\
\text { household income (before-during confinement). }\end{array}$ \\
\hline
\end{tabular}




\section{Arza Porras, et al. - COVID-19 crisis in the Roma community}

\section{Fieldwork procedure}

Each Roma entity participating in the research selected a group of interviewers that had the necessary means at their homes to apply the questionnaire by telephone (computer-assisted telephone interviewing, CATI), including telephone and computer/tablet, in addition to having the necessary time and space. The research team coordinated by the University of Alicante and the Public University of Navarre co-designed the questionnaire in collaboration with the entity promoting the research (FAGA Alicante), providing technical advice for the final version of the questionnaire. The company DAMTEC was in charge of designing the tool to record the data on screen. The research team scheduled online training sessions for the interviewing teams of each entity and acted as technical support and fieldwork control while completing the questionnaires. The team was also in charge of filtering, preparing and analysing data. A descriptive statistical analysis has been carried out using the IBM SPSS 25 statistical tool.

The research did not have specific funding for its development, and it has been possible thanks to the dedication and hours spent working by the people and entities that make up the fieldwork and research team.

\section{Results}

\section{Impact on health}

$12 \%$ of the interviewed people stated that COVID-19 affected someone in their household. $8 \%$ of cases involved cases not confirmed with a diagnosis test and $4 \%$ said to have had confirmation with the test. $5.3 \%$ of cases are obtained from the sample of Roma households considering the number of confirmed cases and the number of suspected cases.

The questionnaire also provided information on the impact that the pandemic and confinement have had on the global health of the interviewed households. Thus, figure 1 shows how state of health tends to worsen during confinement. The percentage of people that consider their health "bad" or "very bad" before the pandemic was $2.6 \%$. However, these figures increased to $17 \%$ during confinement. The percentage of people who 
consider their health "regular" almost doubles, while the percentage of people who consider their health "good" or "very good" decreases from $79 \%$ to $48 \%$.

Eight out of every ten people interviewed state that there has been some sort of health problem other than COVID-19 in their household during confinement. The majority (82\%) refer to problems of "anxiety or depression", while $36 \%$ indicate a "cold", $28 \%$ "digestive issues", $10 \%$ "flu" and $26 \%$ chose the option "other kinds of health problems".

At least one person in half of the households received medical care during confinement (for problems other than COVID-19). In the majority of cases, medical care was telematic (53\%), followed by in-person health services (29\%) and home visits (6\%). Nonetheless, and despite the frequency of stating to have received medical care, $17 \%$ indicated that selfmedication was used at home for health problems other than COVID-19 that arose during confinement.

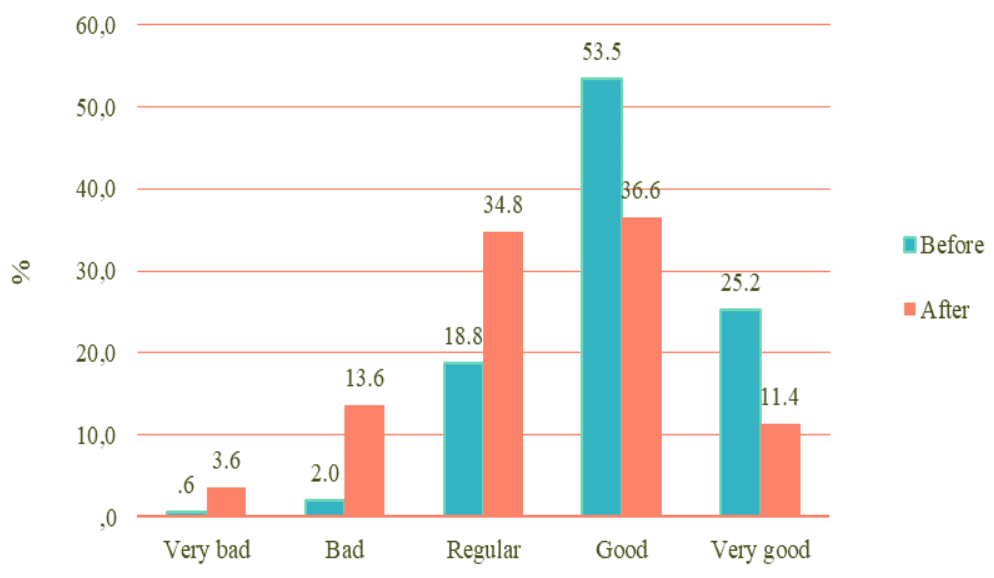

Scale: 1=very bad, 2=bad, 3=regular, 4=good, 5=very good. Median before $=4$. median after $=3$.

Figure 1. Subjective health state before and after confinement.

Interviewers agree on their perception that emotional and mental health problems have been one of the most common health processes during 


\section{Arza Porras, et al. - COVID-19 crisis in the Roma community}

confinement in the interviewed households. In some cases, they refer to anxiety suffered by mothers who have endured situations of great overload during confinement: "...they outlined in terms of mental health that they felt nervous, anxious and scared for the future"; "...women, mothers of several children. They were overwhelmed with housework, looking after children and confinement. Almost all of them ticked the box of anxiety or stress".

They also agree on their perception of the good care provided by the health system. In addition, they include the relevance that family support has had in this case and, at the same time, the emotional and functional impact that the illness has had on family structures: "Families with hospitalised members have been very distressed as they have not been able to see their loved ones and not been able to be with them during their illness..."; "Thanks to the family structure of the Roma community, ill people have been cared for but there has been a lot of distress and suffering".

\section{Impact on educational processes of minors.}

Three out of four homes have been affected by the temporary closure of schools after the state of alarm was declared, as minors were studying their compulsory education. In half of these households (52\%), they declare that their circumstances make it difficult or impossible for some of the school children to continue their studies properly from home.

The analysis of the data in Table 3 allows us to observe several divides that, according to the opinion of the interviewed people, make it difficult to continue studying from home. The first issue is the digital divide which affects $26 \%$ of households that declare that they do not have computer equipment and $23 \%$ indicate that they have difficulties in accessing information. The second issue involves the knowledge transmission divide, understood as the difficulty of providing support at home to help students understand subjects. Here we observe how $18 \%$ of all households indicate that minors cannot understand the content or tasks proposed by teachers and, in addition, $14 \%$ of households state that they do not have anyone in their family who can support the student to understand the tasks or the content of the subjects. The third divide is schooling, where $17 \%$ of 
households consider the lack of instructions by teachers or schools as a difficulty. $15 \%$ reported to not having access to textbooks and the necessary materials. Finally, the aspects linked to individual characteristics, in other words, those related to students' mood, are the least mentioned by the interviewed people. Thus, $12 \%$ referred to the difficulty to continue with studies is a consequence of mood and 5\% due to lack of motivation to study.

Table 4

Problems to follow classes as normal in households with students

Problems

$\%$ valid

Lack of instructions by school and teachers

17.4

Does not have necessary textbooks or material

Does not have IT equipment (mobile, tablet or computer)

Difficulties accessing materials and information provided by teachers

Cannot understand content or tasks

18.4

No one in the home can support the student to understand content or tasks

Emotional reasons (nerves, anxiety, fear, sadness, etc.)

Lack of motivation

Other reasons

4.7

Note: The addition of percentages does not have to be 100 , as the questions are multiple choice.

The interviewers indicate to have perceived concern in families, especially those with children in secondary school, who are afraid of the effect that confinement could have on premature dropouts. They also coincide in observing difficulties linked to the digital divide and the impossibility of offering enough educational support at home. The support from educational centres has been more focused on tackling the digital 


\section{Arza Porras, et al. - COVID-19 crisis in the Roma community}

divide and favouring access to study materials, but less on what we have called the knowledge transmission divide. In this sense, support from Roma associations with educational programmes has been essential.

\section{Impact on employment and income in the household.}

One out of two people interviewed has seen the work activity of members of their household hindered in some way during confinement. $30 \%$ of cases are due to job loss, $12 \%$ as they were not allowed to work, although they were still employed or owned their own company, and $6 \%$ of cases involved the temporary redundancy plan.

Few households have been able to choose to work from home. The majority (90\%) indicate that no one in their home has been able to adapt their job to work from home. In fact, this has negatively impacted the employment of the members of these households.

Figure 2 demonstrates that the general pattern during confinement has involved a reduction in the number of people with economic income in the home. The percentage of households that claim to have only one person with income has increased by 20 points, as well as households that have no income, which has increased by 7 points. On the other hand, the percentage of households that have two people with income decreases by 22 points during confinement, as well as the percentage of households that had three, four or more people with income which decreases from $8 \%$ to $3 \%$ and from $5 \%$ to $1 \%$, respectively.

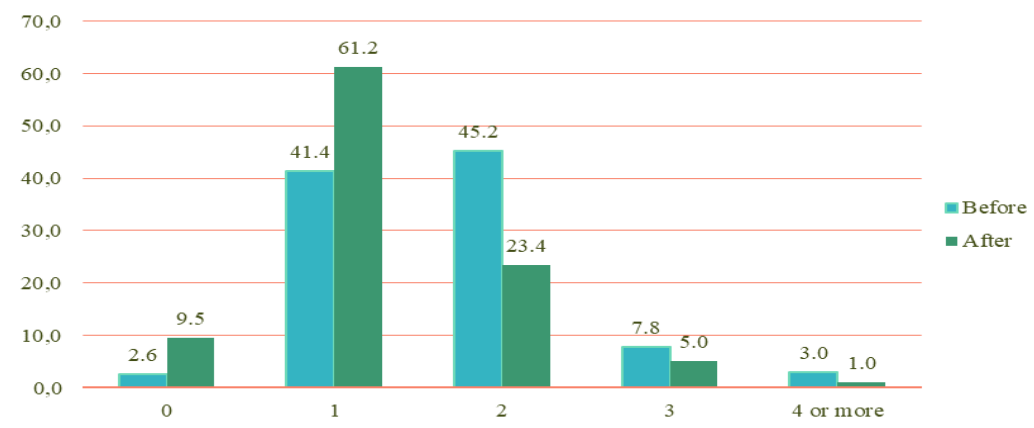

Figure 2. $\mathrm{N}^{\mathrm{o}}$. people in household with income before and after state of alarm. 
Figures 3, 4 and 5 reflect the impact of confinement on the income of the households. More than half of the interviewed people (54\%) state that their household has seen a reduction in income due to the state of alarm. In general, income is low, as around $70 \%$ of interviewees indicate that their household monthly income is equal or lower than $€ 1100$. In terms of income threshold including practically half of the households (from $€ 601$ to $€ 1100), 48 \%$ state to having seen their family income reduced by an average amount of $€ 444$. Nonetheless, in terms of the income thresholds less than $€ 600$, the percentage of households that indicate to have seen a reduction in income by an average of $€ 355$ is especially high.

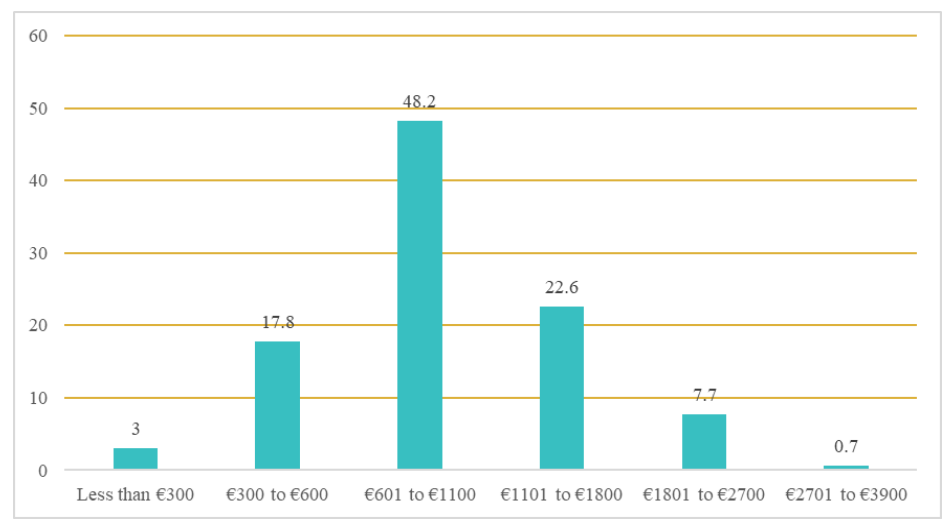

Figure 3. Distribution of families according to threshold income in household.

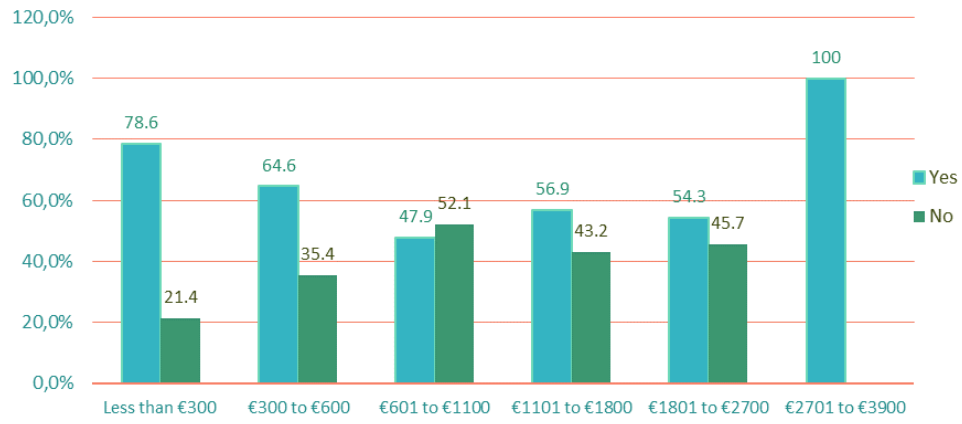

Figure 4. Reduction of household income due to state of alarm, according to household income. 
40 Arza Porras, et al. - COVID-19 crisis in the Roma community

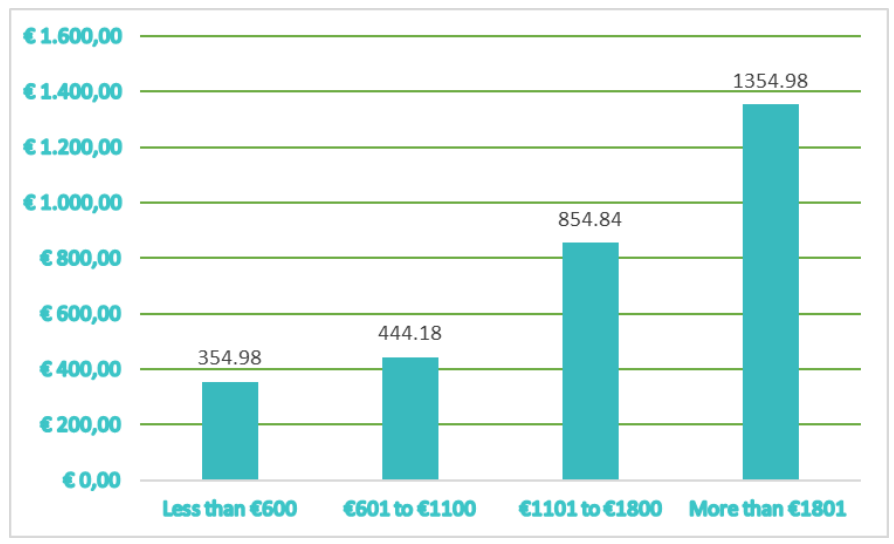

Figure 5. Average amount of household income reduction according to amount of income.

The interviewer's perception regarding the positive and basic protective impact of the minimum insertion income is collected, in those territories where they are more consolidated. However, the great vulnerability of people with very low pensions, benefits or subsidies is commented, or of people who were not registered as self-employed for street selling, cleaning homes, collection of scrap metal or other types of activities: “...they receive basic income and their basic needs were covered."; "...they have indicated a worsening, as their income was complemented with different activities....".

In addition, the difficulties that families have had to face a situation like this stoppage of income has also been observed, due to the low ability to save in their previous employment and precarious income: "The Roma population was in an emergency employment state before the crisis..."; "...the possibility to have savings to survive one or two months is practically zero...".

\section{Impact on basic needs and living conditions.}

The kind of homes that the interviewed families live in are standard, including a kitchen, bathroom, living room and two or three bedrooms, and 
no other rooms. If this information is related to the average household size described in table 2, high levels of overcrowding are not observed in general terms.

Practically all households have equipment and supplies (electricity, drinking water, WC, kitchen, microwave or oven, refrigerator and television). $75 \%$ of households have a motor vehicle. Nevertheless, and in relation to the digital divide mentioned in the section on education, less than half of the households have a computer or tablet. One out of four does not have an internet connection or it is very precarious (mobile phone with limited data).

As one of the most relevant indicators to analyse basic needs, the survey asked several questions related to food needs. Figure 6 shows that eight out of ten households claim to have had difficulties (to a lower or higher extent) in meeting their food needs during confinement. Practically six out of ten homes measure the difficulty as "quite" or "very".

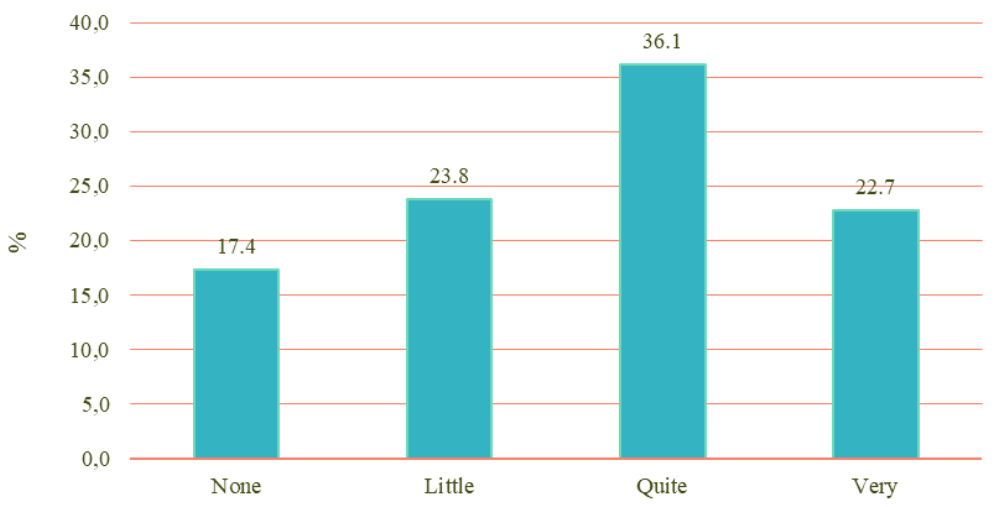

Figure 6. Level of difficulty in relation to food needs during confinement.

Finally, the questionnaire tries to compare the assessment of family life before and during confinement. In general, family life tends to worsen during confinement. If in the period prior to confinement $96 \%$ measured the relationship as "good" or "very good", during confinement this decreased to $79 \%$ and the "regular" category especially rose from $3 \%$ to $16 \%$. However, 


\section{Arza Porras, et al. - COVID-19 crisis in the Roma community}

the percentage of households that value their relationship as "bad" or "very bad" is still very low, going from $0.5 \%$ to $4.3 \%$.

Interviewers have perceived an increase in food poverty, but also how the reduction in income is affecting the ability for families to pay for basic supplies: "Many families do not have enough [money] to pay for supplies and have not paid them for three or four months".

Likewise, we observed how some families have had help from social services in terms of receiving food, but also from Roma and non-Roma associations. In the case of social services, in some cases they have gathered information on the experience of some families regarding the delay in the response: "A large group of families say they have been able to survive thanks to the help of the contributions from associations or the like that have regularly provided them with food".

\section{Impact on perceived and experienced discrimination.}

The health emergency that we have been through in Spain due to COVID19 has not been exempt from situations of social conflict in different contexts. In this sense, the media has reported on events related to the Roma community and discrimination. These events have led to including a series of indicators in the survey related to the perception of this problem by the Roma.

When questioned about the perception of discrimination towards the Roma population from its members since the beginning of the state of alarm, 56\% of the interviewed people responded that it had increased, 33\% consider it has not and $8 \%$ do not know. When asked about experiences of discrimination during the state of alarm by the members of the household, $20 \%$ stated that they or a member of the household had directly experienced this problem.

Information was also collected through open-ended questions for the interviewed people to describe the discrimination situations they had experienced. The answers have been summarised into a series of items that include the main experiences. As observed in table 5, the interviewees answered that they or a member of their household had experienced different types of discrimination. 6\% suffered accusations of COVID-19 contagion, $2 \%$ negative comments, $2 \%$ disrespectful treatment, and another 
$2 \%$ answered that they had received a particular accusation based on widespread behaviour or prohibition of some common aspect or rule. Around $1 \%$ indicated to have had experienced discrimination through situations of avoidance, accusation of not complying with confinement, feeling observed or being insulted.

Table 5

of suffered discrimination

\begin{tabular}{ccccc} 
& Frequency & \% & \% valid & \% accumulated \\
\hline Accusation of COVID contagion & 32 & 6.5 & 33.3 & 33.3 \\
Negative comments & 12 & 2.4 & 12.1 & 45.4 \\
$\begin{array}{c}\text { Disrespectful treatment } \\
\text { Particular accusation of } \\
\text { widespread behaviour or } \\
\text { prohibition of something }\end{array}$ & 11 & 2.3 & 11.8 & 57.2 \\
$\quad$ common to all & 10 & 2.0 & 10.4 & 67.6 \\
$\quad \begin{array}{c}\text { Avoidance } \\
\text { Not complying with confinement }\end{array}$ & 6 & 1.3 & 6.8 & 82.2 \\
$\begin{array}{c}\text { Feeling observed } \\
\text { Insults }\end{array}$ & 6 & 1.3 & 6.7 & 88.9 \\
Stereotypes & 4 & .9 & 4.4 & 93.2 \\
Abandonment by authorities & 3 & .7 & 3.4 & 96.7 \\
Others & 3 & .5 & 2.8 & 99.5 \\
Total & 1 & .1 & .5 & 100.0 \\
\hline
\end{tabular}

Figure 7 represents the degree of concern about discrimination problems during confinement, and on a scale of 0 to 10 where 0 means "no concern" and 10 the "highest concern", it is observed that more than half of the interviewed population (56\%) responded to having a very high level of uneasiness (between 8 and 10). Overall, more than 8 out of 10 responses $(86 \%)$ are above 5. 


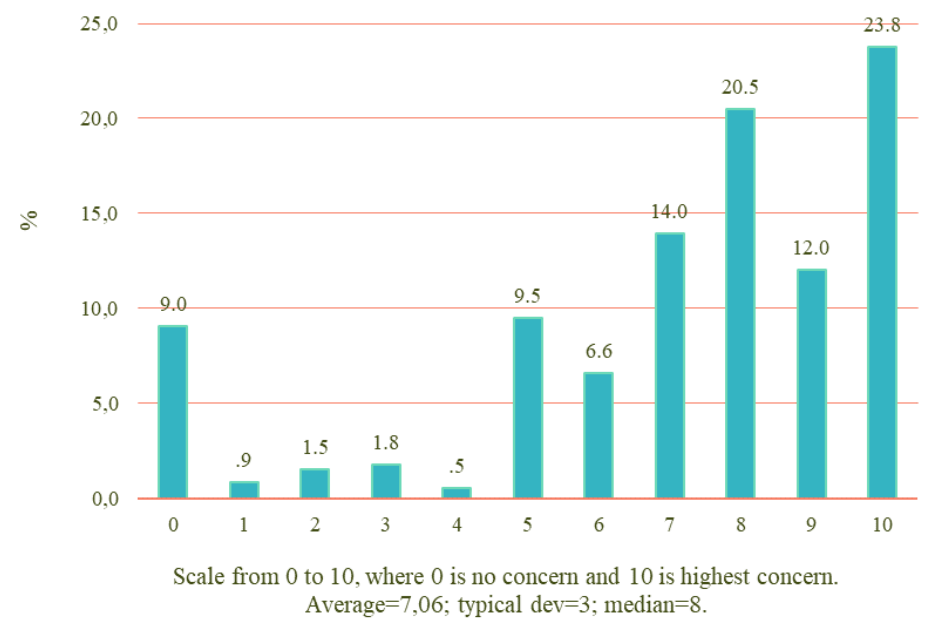

Figure 7. Degree of concern regarding discrimination issues during state of alarm

According to the perception of the interviewers, the media and social networks are the main ways through which discrimination occurs, according to the interviewees: "...those who use social networks more say so, they had noticed an increase in discrimination since the state of alarm with messages and hoax messages that damage the community a lot".

In addition, they express that discrimination has been one of the questions that has most bothered some interviewees, especially when referring to discrimination suffered in first person: "When talking about feeling discriminated, I have noticed that it was an uncomfortable question, they felt bad...it was the only question where I was asked if it was anonymous...";

“...they say that their family and them have not been directly affected. If you speak to them for longer, in the majority of cases they have suffered discrimination: bad looks, neighbours who stop saying hello, disrespect in shops and even problems in medical centres... but they do not indicate it as discrimination or racism towards them". 


\section{Discussion}

The results show the important multidimensional impact that the pandemic has had on households that were already affected by different cases of social exclusion and inequality, and that had barely been able to recover from the previous economic crisis. The FOESSA 2014 survey, which analysed the impact of the 2008 crisis on the Spanish population, indicated that around $72 \%$ of the Roma population were in a situation of moderate or severe social exclusion (Damonti and Arza, 2015).

In terms of health, the incidence of the pandemic is observed in a worsening of self-perception of health during confinement and a negative impact on mental health. Available previous studies already represented a clear situation of inequality in the health of the Roma population, both in self-perceived health and in lifestyles, or in accessing certain health services (La Parra, Gil and de la Torre, 2016). In the study by the nongovernmental organisation Cáritas on the impact of the pandemic on its user population, reference is also made to increased anxiety and/or difficulty sleeping (Cáritas, 2020).

In terms of education, half of the households refer to minors having difficulties continuing their studies from home. Both the detected digital divide and the schooling or transmission of knowledge divide could contribute to a worsening in education for students who, according to the available studies, were already in a serious situation of educational inequality. For example, $17 \%$ of the Roma population over 16 years of age have completed their mandatory secondary educational, versus $80 \%$ of the general population (De la Rica et al., 2019). The Cáritas study also detected the impact of the digital divide on school performance (Cáritas, 2020), as well as the study conducted by FSG (2020) and the Central Council of German Sinti and Roma (2020) that, in addition to the digital divide, also detected what they called the schooling and the transmission of knowledge divide.

One out of two homes has seen their jobs affected due to confinement. In addition, this work is characterised to a large extent by underemployment, precariousness, low salary and low qualifications (De la Rica et al., 2019). Likewise, more than half of the households have suffered 
a significant reduction in income. One effect of this has been the increased difficulties in accessing basic food. The FOESSA 2014 survey spoke about moderate and severe poverty percentages of $71 \%$ of the Roma population (Damonti and Arza, 2015). The FSG study on the impact of the pandemic on its user population coincides in detecting a relevant increase in households with problems in accessing food (FSG, 2020). Additionally, research carried out in the United Kingdom on the impact of COVID-19 on ethnic groups shows how the precarious characteristics of the relation with the labour market influence that certain social groups have less economic capacity to face income crises as that caused by the pandemic (Platt and Warwick, 2020). On the other hand, Cáritas detects an impact eight times higher than the unemployment rate on its user population during confinement, and a high reduction in income from formal jobs, but especially from those linked to informal jobs (Cáritas, 2020).

There has also been an increase in perceived discrimination in households. In fact, in the process of social exclusion that the Roma population suffers, the whole set of factors mentioned above interact within a systemic framework that different authors have called "anti-gypsy" (Garcés, 2016; Jiménez, 2016; Van Baar, 2014) and in which social and institutional discrimination play a very relevant role (McGarry, 2017; Arza \& Carrón, 2015). A report referring to the Balkans and Turkey even mentions the possibility of violent racism caused by false rumours on the responsibility of Roma people in the spreading of the pandemic (Central Council of German Sinti and Roma, 2020).

Although this study does not identify the differences in terms of gender in the analysed variables due to its methodological structure, previous scientific evidence shows that Roma women, as also observed in non-Roma women, are more affected by different health problems, social conditions such as unemployment, and higher responsibility to care for the family (MSSSI, 2016). Therefore, different gender roles within the family and gender inequality itself in the home (as in the general population) are the basis to manage the pandemic in the family, foreseeing a greater negative impact in dealing with COVID-19 on the health of women. Supporting children's education, caring for dependent elderly members of the family or organizing the household, as well as having difficulties in accessing economic resources and materials, would all have mainly depended on 
women, if we take the foregoing knowledge as a hypothetical basis (European Union Agency for Fundamental Rights, 2019).

Fortunately, the results of the survey also show protective factors, such as the cohesion of the extended family, which continues to remain strong, thus cushioning the impact of the pandemic. The mutualism of the Roma community (Filigrana, 2020) has helped to cope with the needs, losses and damages caused by this crisis better. In addition to this traditional mutualism, associations have played a fundamental role in supporting many Roma families during confinement.

In short, COVID-19 has highlighted the pre-existing inequalities in our country, also in the case of the Roma community. The impact of the pandemic on the most vulnerable sectors of our society highlights the insufficient prior investment in social housing, inclusive education, dignified and safe employment, minimum insertion income, community health care, or in the fight against discrimination, among other needs. Thus, policies after the pandemic must include a multidimensional perspective and an approach of an intersectoral intervention towards equality. It would also be essential to guarantee the population's real participation, in this case of the Roma population and civil society, when designing, developing and assessing all the policies.

Finally, in terms of the limitations of this study, and as mentioned in the methods section, the results of this research cannot be extrapolated to the entire Roma population. However, they do represent a relevant approximation to the situation of the Roma community in a situation of greater vulnerability, the one with which the Roma associations work. Differences between men and women in terms of the topics can also not be observed, as the provided answers refer to the members of the household as a whole. This is a particularly invisible sector, which would have been difficult to access without the involvement of the entities that have participated in the study.

On the other hand, the data provided on the incidence of COVID-19 cannot be compared to the data obtained in the seroprevalence study conducted by National Centre of Epidemiology/ Health Institute Carlos III. There are various reasons for this: it is not a population with the same age structure as that of the whole of the Spanish population surveyed in it; our study does not include probability sampling; asymptomatic people have not 
been included; and its measurement is based on self-declaration. In other words, the information in this research does not allow to report on a greater or lesser incidence of COVID-19 in the Roma population.

\section{Acknowledgements}

We would like to thank the associations of the Roma network Equi-Sastipen-Rroma for their essential collaboration, and especially to: FAGA (Region of Valencia), Gaz Kalo (Navarre), Nevipen (Bizkaia), Red Artemisa (Madrid) and UNGA (Asturias). We would also like to recognise the effort of everyone at the associations who have taken part as interviewers: Nerea Abadiano, Maitane Aznar, Regina Borja, Mª . Félix Camacho, Mercedes Campaña, Luisa Cortés, Saturnino Dual, Marta de Gregorio, Cristina de la Vega, Jacinta Estévez, Graciela Fernández, Amaya Fernández, Ruth García, Mª Eugenia González, Carmen Jiménez, Antonio Jiménez, Silvia Jiménez, Vanessa Jiménez, Carmen Jiménez, Virginia López, Elena López, Manuela Mayoral, María Martinez, Amara Martínez, Marlen Menéndez, Karina Montoya, Raquel Oliver, Ana Puertas, Jesús Ramírez, Lara Sánchez,

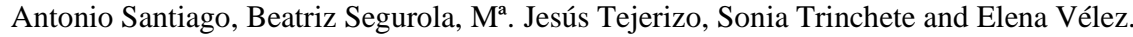

\section{References}

Arza, J.; Carrón, J. (2015). Comunidad gitana: la persistencia de una discriminación histórica. OBETS. Revista de Ciencias Sociales. Vol.10, no.2: 275-299. https://doi.org/10.14198/OBETS2015.10.2.01

Cáritas Española (2020). La crisis de la COVID-19. El primer impacto en las familias acompañadas por Cáritas. Madrid: Cáritas Española. Retrieved from: https://www.caritas.es/producto/el-primer-impactoen-las-familias-acompanadas-por-caritas/

Central Council of German Sinti y Roma (2020). Alarming situation of Roma communities in the Western Balkans and Turkey through the COVID-19 pandemic. Retrieved from: https://zentralrat.sintiundroma.de/en/alarming-situation-of-romacommunities-in-the-western-balkans-and-turkey-through-the-covid$19-$

pandemic/?utm_source $=\mathrm{WHO} \% 2$ FEurope+mailing+list\&utm_campa ign $=\mathrm{b} 4 \mathrm{c} 5 \mathrm{~b} 7 \mathrm{~d} 2 \mathrm{a} 8$ -

EMAIL_CAMPAIGN_2020_06_19_10_59\&utm_medium=email\&u tm_term=0_60241f4736-b4c5b7d2a8-102208393

Cook, B.; Wayne, G.F.; Valentine, A.; Lessios, A.; Yeh, E. (2013).

Revisiting the evidence on health and health care disparities among 
the Roma: A systematic review 2003-12. Int. J. Public Health, 58, 885-911. https://doi.org/10.1007/s00038-013-0518-6

Damonti, P.; Arza, J. (2015). Exclusión en la comunidad gitana. Una brecha social que persiste y se agrava. En F. Lorenzo, VII Informe sobre exclusión y desarrollo social en España (pp. 1-34). Madrid:

Fundación FOESSA. Retrieved from:

https://www.foessa2014.es/informe/uploaded/documentos_trabajo/15 102014151523_8331.pdf

De la Rica, S. (dir.) et al. (2019). Estudio comparado sobre la situación de la población gitana en España en relación al empleo y la pobreza 2018. Madrid: Fundación Secretariado Gitano. Retrieved from: https://www.gitanos.org/centro_documentacion/publicaciones/fichas/ 129378.html.es

European Commission (2015). Indicators for promoting and monitoring Responsible Research and Innovation Report from the Expert Group on Policy Indicators for Responsible Research and Innovation. Retrieved from:

https://ec.europa.eu/research/swafs/pdf/pub_rri/rri_indicators_final_v ersion.pdf\#view $=$ fit\&pagemode $=$ none

European Union Agency for Fundamental Rights (2019). Second European

Union Minorities and Discrimination Survey, Roma women in nine EU Member States. Retrieved from:

https://fra.europa.eu/sites/default/files/fra_uploads/fra-2019-euminorities-survey-roma-women_en.pdf

Filigrana, P. (2020). El Pueblo Gitano contra el Sistema-Mundo.

Reflexiones desde una militancia feminista y anticapitalista. Ciudad de México: Akal.

FSG (2020). Impacto de la crisis del COVID-19 sobre la población gitana.

Madrid: Fundación Secretariado Gitano. Retrieved from:

https://www.gitanos.org/centro_documentacion/publicaciones/fichas/ 129378.html.es

Garcés, H. (2016). El racismo antirom/antigitano y la opción decolonial.

Tabula Rasa. Revista de Humanidades. N. 25: 225-251.

Janevic T.; Jankovic J.; Bradley E. (2012). Socioeconomic position, gender, and inequalities in self-rated health between Roma and non-Roma in 
50 Arza Porras, et al. - COVID-19 crisis in the Roma community

Serbia. Int J Public Health; 57: 49-55.

https://doi.org/10.1007/s00038-011-0277-1

Jiménez, N. (2016). ¿El antigitanismo afecta a la salud? En D. La Parra y

N. Jiménez, Sastipen aj Rroma: Desigualdad en salud y comunidad gitana (43-61). Alicante: Universidad de Alicante.

La Parra, D.; Arza, J.; Estévez, J. (2020). Health indicators of the National Roma Integration Strategy in Spain in the years 2006 and 2014.

European Journal of Public Health, 1-5.

https://doi.org/10.1093/eurpub/ckaa070

La Parra Casado, D.; Gil González, D.; de la Torre Esteve, M. (2016). The social class gradient in health in Spain and the health status of the Spanish Roma. Ethn. Health, 21, 468-479.

https://doi.org/10.1080/13557858.2015.1093096

McGarry, A. (2017). Romaphobia: the last acceptable form of racism.

London: Zeb Books Ltd.

MSSSI (2016). Segunda encuesta nacional de salud a población gitana.

Madrid: Ministerio de Sanidad, Servicios Sociales e Igualdad.

Retrieved from:

https://www.mscbs.gob.es/profesionales/saludPublica/prevPromocio n/promocion/desigualdadSalud/docs/ENS2014PG.pdf

MSPS/FSG (2009). Hacia la equidad en salud. Estudio comparativo de las encuestas nacionales de salud a población gitana y población general de España, 2006. Madrid: Ministerio de Sanidad y Política Social y Fundación Secretariado Gitano. Retrieved from:

https://www.mscbs.gob.es/profesionales/saludPublica/prevPromocio n/promocion/desigualdadSalud/ENS2006PG.htm

Platt, L. y Warwick, R. (2020). Are some ethnic groups more vulnerable to COVID-19 than others? London: The Institute for Fiscal Studies.

Retrieved from: https://www.ifs.org.uk/inequality/wpcontent/uploads/2020/04/Are-some-ethnic-groups-more-vulnerableto-COVID-19-than-others-IFS-Briefing-Note.pdf

Van Baar, Huub. (2014). The Emergence of a Reasonable Anti-Gypsyism in Europe. En Agarin, T., editors. When Stereotype Meets Prejudice: Antiziganism in European Societies, edited by Timofey Agarin, 25. Stuttgart: ibidem-Verlag. Retrieved from: 
https://www.academia.edu/8170981/The_Emergence_of_a_Reasona ble_Anti-Gypsyism_in_Europe_2014_

Voko, Z.; Csépe, P.; Németh, R.; Kósa, K.; Kósa, Z.; Széles, G.; Ádány, R (2009). Does socioeconomic status fully mediate the effect of ethnicity on the health of Roma people in Hungary? J. Epidemiol Community Health; 63: 455-460. https://doi.org/10.1136/jech.2008.079715

Javier Arza Porras is Associate Professor at the Public University of Navarre, Spain.

Diana Gil-González is Associate Professor at the University of Alicante, Spain, and member of CIBER of Epidemiology and Public Health in Spain.

Lluís Català-Oltra is Assistant Professor at the University of Alicante, Spain.

Francisco Francés García is Associate Professor at the University of Alicante, Spain.

María Eugenia González Angulo is Advanced Technician in FAGA (Federación Autonómica de Asociaciones Gitanas de la Comunidad Valenciana) and member of EquiSastipen-Rroma Network.

Maria Félix Rodríguez Camacho is Responsable of Health Area in FAGA (Federación Autonómica de Asociaciones Gitanas de la Comunidad Valenciana) and member of EquiSastipen-Rroma Network.

Maria José Sanchís Ramón is PhD student in Sociology (FPU17/01869 Ministry of Science, Innovation and Universities, Government of Spain) in School of Doctorate (EDUA), Business, Economy and Society program of the Faculty of Economic and Business Sciences, University of Alicante.

Belén Sanz-Barbero is Scientific Researcher of Carlos III Health Institute, Spain, and member of CIBER of Epidemiology and Public Health in Spain.

Carmen Vives-Cases is Professor at the University of Alicante, Spain, and member of CIBER of Epidemiology and Public Health in Spain.

Daniel La Parra Casado is Associate Professor at the University of Alicante, Spain.

Contact address: javier.arza@unavarra.es 